\title{
The world in the post-truth era or how too much love of TINA will kill you
}

\author{
Jarl K. KAMPEN \\ University of Antwerp, Belgium
}

\begin{abstract}
:
Aim: The temptation to provide simple answers to complex problems exists for politicians and scientists alike. This essay attempts to briefly outline the complexity of present day problems at global level, taking as a starting point the question "how quick will the EU collapse?"

Design / Research methods: The nature of the topic calls for a holistic interpretative approach rather than a systematic reductionist one. Brief discussions are given of separate yet interconnected, causally related and overlapping natural and social research domains, illustrating the need for qualified multidisciplinary spokesmen able to separate facts from "alternative facts."

Conclusions / findings: Making the simple anthropological observation that people can choose policies that are self-destructive does not make social science politicized or value-biased. A society that considers global warming, depletion and pollution caused by fossil fuels as mere externalities makes a demonstrable erratic choice. Because one of the major goals of science is to establish (in)validity of "common sense," it is the duty of academics to tell our students that societies, including entire scientific departments, can make consistent erratic choices.
\end{abstract}

Originality / value of the article: This essay may help scholars and practitioners to start to look at their research domain in a (much) wider global context.

Keywords: monetary system, market system, inequality, climate change, depletion

JEL: P10, P28, P36, Q20, Q40, Q50.

E-mail: jarl.kampen@ unantwerp.be

Received: 26-02-2017, Revised: 24-05-2017, Accepted: 25-05-2017 


\section{Introduction}

Things fall apart; the centre cannot hold;

Mere anarchy is loosed upon the world,

The blood-dimmed tide is loosed, and everywhere

The ceremony of innocence is drowned;

The best lack all conviction, while the worst

Are full of passionate intensity.

— William Yates, “The Second Coming” (1919; also, see Toulmin 1990: 66)

I wish to thank the editor of Central European Review of Economics and Management for the invitation to contribute to the subject "Disintegrating Europe how quick will the EU collapse?" This essay is to explain why I have to decline on such assignment. The main reason is that I lack the scientific authority to write in this area. Admittedly, I have published on governance (Kampen 2009), economy (Kampen 2012), sociology (Kampen 2010), ecology (Marwijk et al. 2012), public management (Kampen et al. 2006, 2003; Kampen, Snijkers 2003) and climatology (Kampen 2011), sometimes in major, sometimes in minor journals, but that doesn't make me an authority on the possible decline of Europe. Allow me to elaborate on my reasons a little.

In March 2003, together with my spouse, I visited the USA in order to attend a conference. At customs of Dulles airport, Washington DC, first my spouse was interrogated about the purpose of her visit, and her statements were then crossreferenced with mine. The fear of US customs that we intended to stay as illegal immigrants was totally unjustified, we're both very fond of Europe, but how could they know. So they fired a number of questions. Was it my first visit to the US? Yes. What was the reason of my stay? I explained that I came to attend a conference on public administration, and would present a paper about the reasons why people distrust government. After an uncomfortable pause, during which I tried to figure out in what way I contradicted my spouse's statements, the person from customs said: "What took you so long?" 
So we were cleared to enter the Promised Land. Arriving on a Saturday, we had time to visit the city center, and witnessed a mass of people near the Mall protesting against the planned invasion of Iraq (protests about which you would not learn on $\mathrm{CNN}$ ). The next evening, on Sunday, while in the hotel restaurant, the invasion was officially announced by Bush Jr., and while we were close to tears, the American guests actually enjoyed the news, some men dressing in stars-and-stripes ties, making us feel totally alien. We stayed for two weeks, a first week for the conference (and visiting DC), and a second driving around in Maryland, Virginia, Kentucky, and North Carolina, in a rented Chevrolet. During this sightseeing tour we were consistently confirmed in our notions that we would never feel at home in the USA. At a bed-and-breakfast in Kentucky, the owner showed us an enormous gun (was it a Colt Single Action Army Peacemaker?) that he kept in a drawer, supposing that it would make us feel safe in his place. The supermarkets had 50 different kinds of Cheddar but not a single piece of Dutch, Danish, or Swiss cheese. The city centers were ugly, abandoned with white washed windows, the look and feel of Bruce Springsteen's Nebraska album all over the place, and with few exceptions simply not worth visiting. On the roads and highways, people would open the windows of their SUVs and throw the garbage of their fast food diners out on the street, a behavior we witnessed everywhere except in the Reserves which were impeccably clean. Outside the reserves, any spot that looked interesting on the map (a waterfall, a river bank, a viewpoint of some kind) was private owned and fenced off. In conversations with the local people, we were criticized for not fighting Saddam Hussein (recall that Germany, France, and Belgium, where we live, were not part of the "coalition of the willing"). People upheld the notion that the USA should adopt an isolationist policy using their own unlimited resources, and leaving the world to its own problems (not acknowledging of course, that the USA was an active player in the creation of many of these problems). In short, we were happy to be Europeans, and to be going home soon.

But we are 14 years later now, a relatively short period of time during which Europe has changed to become near unrecognizable. Simultaneously my career has changed direction. I was once a psychologist, became a social scientist with a degree, was active as a postdoc for several years in public management studies, went 
on to become a political scientist, compiled Dutch official statistics for a while, only to become an assistant professor teaching research methodology at BSc, MSc and $\mathrm{PhD}$ level, in a multidisciplinary context (see Tobi, Kampen 2017). In order to be fully convincing that the task to address the question "how quick will the EU collapse?" is beyond my capacities, I provide an outline of the topics and scientific fields that need to be covered in order to intelligently arrive at an answer. The nature of the topic calls for a holistic interpretative approach rather than a systematic reductionist one, because the topic concerns separate yet interconnected, causally related and overlapping natural and social research domains, and requires qualified multidisciplinary spokesmen able to separate facts from "alternative facts." A layout of these topics is in Figure 1, which will convince you that I'm not the multidisciplinary centipede that you're looking for. I hope the diagram helps you in finding someone apt to the job. In the next sections, I will briefly discuss the elements in the diagram, along with the little I know about these things, in order to arrive at a highly preliminary conclusion in the final section.

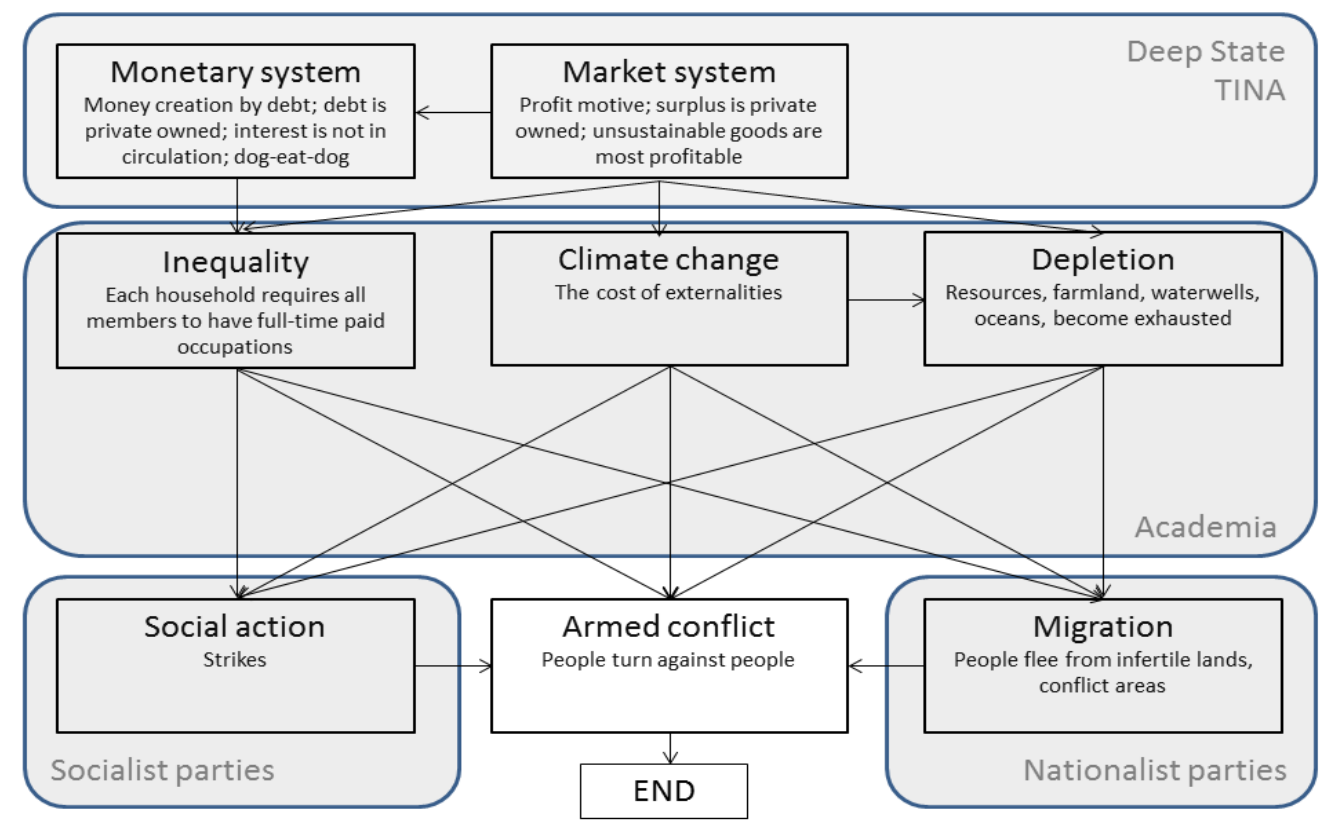

Figure 1. The global system

Source: author's own contemplations 
THE WORLD IN THE POST-TRUTH ERA OR HOW TOO MUCH LOVE OF TINA WILL KILL YOU

\section{There is no alternative}

\section{The monetary system}

"There is no alternative (shortened as TINA) was a slogan often used by the Conservative British Prime Minister Margaret Thatcher."

- Wikipedia

"No-one would remember the Good Samaritan if he'd only had good intentions; he had money as well."

- Margaret Thatcher

"The debt limits have to come down. The whole world of debt has to be changed as far as this country is concerned. We have to create jobs and we have to create them rapidly because if we don't things are just going to head in a direction that's going to be almost impossible to recover from."

- Donald Trump

The purpose of money as the means to pay prices of commodities and services is to allocate labor. For example, I need bread today and in the future, but the baker may have no need for a course in statistics and methodology for years to come. So I pay the baker money, which he can cumulate or spend on other items paying other people, some of whom may have a use for the labor that I happen to sell. Money came into being as an aid not an aim. Accumulating money is an aim of many people because it gives the owner power to allocate labor. If you accumulate a lot of money, you can allocate a lot of labor - ultimately enough labor to force entire nations into self-selected directions (invariably those that will make one accumulate more money and power). An institution that has the monopoly to create money has of course, unlimited power. Nowadays, money is introduced to the market by means of bank credit (Grazania 2003: 11). In other words, in our monetary system, money is debt, the debt is owed to the banks, and the banks are owned by its shareholders (mainly from the private sector). 
Elsewhere I have tried to analyze how monetary systems (including so-called Islamic banking) invariably create unserviceable debt: sums of money that have to be repaid to the bank owners in kind (Piketty 2013: ch. 15; Kampen 2011). The periodic shake-ups of the financial system are those moments when society at large has to cough up the unserviceable debt. Financial crises facilitate the quick accumulation of money. For instance, stock market crashes make high volumes of stock change hands from the middleclass to the upperclass, so that today the rich $1 \%$ have the ownership papers of $50 \%$ of all assets worldwide (Oxfam 2015). Such crashes have no apparent origin in the real economy (ignoring all posterior explanations by financial experts), but are caused by a demand for money by lenders which forces borrowers to liquidate their stocks, bonds and real estate. For instance, prior to, during, and posterior to the financial crises of 1929 and of 2007 all resources for production were in place. There was no pandemic that flattened the labor force, nor were there any important collapses or fires in factories or mines. Scientific literature provides no evidence that there were issues with the labor force, transportation infrastructure, or with the materials needed to produce. Everything was in place, except for a shortage of money. The public had overborrowed. Already in the $18^{\text {th }}$ century, overborrowing money was the major reason for the disappearing of the small landowner (Johnson 1909: 118). But why have sophisticated, profitmaximizing lenders so often overlent, askes Joseph Stiglitz (2006). Lenders encourage indebtedness because it is profitable, he replies (p. 216, italics added).

The reason why governments had no money to continue economic activity in 2007 (and at the next crisis) was the monetary system in general, and interest on loans in particular. Interest means that banks try to extract more money from society than it puts into society, so with mathematical certainty society remains with debt that periodically has to be repaid in kind (Grazania 2003: 31). And realize that someone's profit is someone else's debt. For governments from the $1980 \mathrm{~s}$ on, paying in kind meant surrendering public goods to privatization (Kampen 2009). Today governments have no other source of income than taxes, and they have to borrow money like any ordinary person in the street and on the same conditions. This means that governments depend on the courtesy of the lenders. Among many 
THE WORLD IN THE POST-TRUTH ERA OR HOW TOO MUCH LOVE OF TINA WILL KILL YOU

other nations that preceded their fate, the Greek people can tell you what that courtesy entails.

\section{The market system}

"There are significant differences between the American and European version of capitalism. The American traditionally emphasizes the need for limited government, light regulations, low taxes and maximum labor-market flexibility. Its success has been shown above all in the ability to create new jobs, in which it is consistently more successful than Europe."

- Margaret Thatcher

"We will make America strong again. We will make America proud again. We will make America safe again. And we will make America great again."

- Donald Trump

A profitable business not only sells products for more money than they're worth. It has to sell these products on a continuous basis. And in order to be able to sell products continuously they must be manufactured with the lowest quality possible, so that they are in need of continuous replacement. A product that can be repaired will not be replaced, so the products must be irreparable too. If in addition, governments continue to value economic productivity over environmental pollution, the business is a goldmine to its owners, who use the profits to allocate labor to make more profit, until they literally own the entire free market. That is, the entire Planet Earth including you and me. Did not Erasmus advise Charles I already in 1517 that people good in collecting wealth are not necessarily good in formulating policy? Perhaps he should have told that to the people of the USA .

The market system is designed for people interested in making profit, that is, interested in accumulating money in order to have power over people's labor. Why people want more money than needed to maintain a comfortable life beats me. For the few times that I fly I don't need to own an airplane. I can drive only one car, live in one house, look at one TV, cannot tell cava from champagne, and don't like caviar. I have no interest in converting people to my religion or in exercising power 
over them. Of course every now and then, I want my car faster, my house more comfortable, my TV screen bigger, my phone smarter, my sparkling wine pink, my children to obey without commenting - but these things, as you well know, are ridiculously unimportant when compared to the health and happiness of you and your loved ones. It will be easy to let some if not all of these materialistic desires go. It is a pity in this respect that health care is increasingly privatized (read: made available to the privileged only).

The monetary system and the market system are the best systems ever invented and any apparent shortcomings are the fault of government intervention. Even when they are the direct cause of the social and environmental externalities that I discuss below, there is no alternative. There. Is. No. Alternative. So we might as well love Tina.

\section{Social and environmental externalities}

\section{Inequality}

"I think we've been through a period where too many people have been given to understand that if they have a problem, it's the government's job to cope with it. 'I have a problem, I'll get a grant.' 'I'm homeless, the government must house me.' They're casting their problem on society. And, you know, there is no such thing as society. There are individual men and women, and there are families. And no government can do anything except through people, and people must look to themselves first. It's our duty to look after ourselves and then, also to look after our neighbor. People have got the entitlements too much in mind, without the obligations. There's no such thing as entitlement, unless someone has first met an obligation."

- Margaret Thatcher

"I don't like losers." 


\section{KILL YOU}

There was a short period in Europe when a single income was sufficient to maintain a family. This period is over. Real income has been dropping since the seventies onward (the "long downturn"; see Brenner 1998). Despite all robots, automation, industry, mass agriculture, etc., servicing a mortgage for an apartment or house requires both partners to have payed occupations. In other parts of the world, still much worse off, child labor is normal. These children make the trousers and dresses for our own children. Access to education and healthcare is a fiction in the "developing" part of the world, and is becoming history in the "developed" part. The banks are consuming all money once reserved for the retired, the sick, the unfortunate, and the youth. For many people, life is simply becoming unbearable, which drives them to social action, migration, or worse.
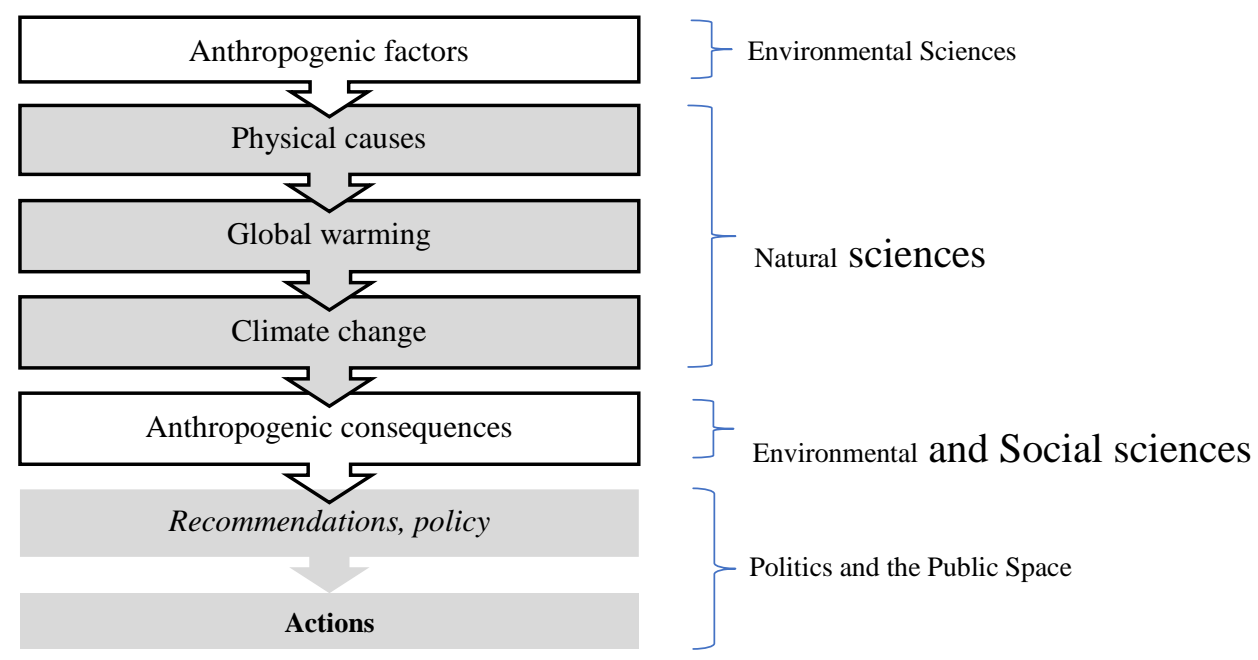

Figure 2 - The interdisciplinary nature of the debate on AGW

Source: author's own contemplations

\section{Run-away greenhouse}

"An atmosphere of that gas would give to our earth a high temperature; and if as some suppose, at one period of its history the air had mixed with it a larger proportion than at present, an increased temperature from its own action as well as from increased weight must have necessarily resulted." 
Knowledge of the warming effect of $\mathrm{CO}_{2}$ dates back to experiments conducted by John Tyndall in the nineteenth century. And since the evidence that humans are changing the composition of the Earth's atmosphere by increasing greenhouse gas levels (including $\mathrm{CO}_{2}$ ) and decreasing oxygen levels is cumulating (e.g. Stuiver et al. 1984; Quay et al. 1992), the anthropogenic global warming (AGW) theory can be considered to be firmly grounded in solid verifiable scientific theory. The only question that cannot be answered straightaway is exactly how much of fluctuations in the Earth's temperature can be attributed to anthropogenic factors. But AGW is without doubt very inconvenient for our beloved Tina.

"Watch your thoughts, for they will become actions. Watch your actions, for they'll become habits. Watch your habits for they will forge your character. Watch your character, for it will make your destiny."

- Margaret Thatcher

"Windmills are going to be the death of Scotland and even England if they don't do something about them. They are ruining the countryside."

— Donald Trump

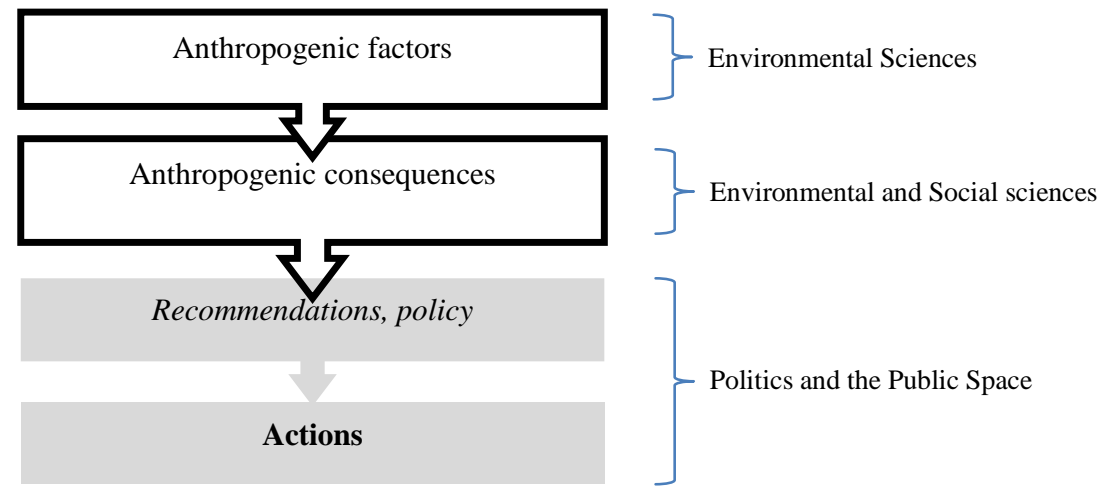

Figure 3 - The simplistic debate on AGW

Source: author's own contemplations 
Nobody knows whether we have already reached the point of run-away green house, but status quo will make it certainty whereas radical changes make it a probability. However, even this probability is contested by high ranking politicians, who refer to apparent and fictitious debate in science. The complexity of AGW arises from the fact that it presupposes a chain of interrelated phenomena, each requiring different expertise for studying (e.g. Corner et al. 2012; see Figure 2). The core of the theory is within the realm of the natural sciences: notably (quantum) physics, cosmology and climatology. The natural sciences are well in a position to determine physical causes (e.g. characteristics of GHGs, solar activity, etc.) of warming, and in measuring, estimating and predicting effects of global warming on the Earth's climate (e.g. droughts and floods, vanishing of Polar ice caps, etc.), up to a certain level of detail. However, when it comes to determining the relative impact of anthropogenic factors that contribute to physical causes of AGW (e.g. industrialization, cement production, transportation, deforestation), in part or in whole the natural sciences must rely on other scientific disciplines (geography, economics, environmental sciences) for the supply of data. Also, other disciplines than the natural sciences are responsible for establishing anthropogenic consequences (e.g. changed or decreased biodiversity and fertility, soil erosion, etc.). And finally, a group of specialists succinctly different from scientists altogether is responsible for formulating adequate remedial policies and follow up on the public debate.

Elsewhere I have argued that when the debate becomes more focused on falsification rather than verification of the AGW hypothesis, the case for validity of the latter theory could become stronger (Kampen 2011). Whereas natural scientists tend to believe that criticism of AGW, if at all possible, should be directed at the causal chain "physical causes $\rightarrow$ global warming $\rightarrow$ climate change" (in short, PGC), some social scientists and many politicians believe that PGC is part of a belief system that can be rejected or accepted at will. At the level of a society, ultimately the taxpayers decide what is to be taught in public schools and how public money is to be spent, says Feyerabend (1987). At the level of scientists, consensus is accepted as a proxy for the truth (Swanborn 1997). Because social scientists and politicians have unsubstantial understanding of natural sciences, their focus is the 
simplified chain going from anthropogenic causes to anthropogenic consequences (Figure 3). Possible critique of AGW can thus be directed at the presupposed human causes (do they exist?), the presupposed effects (do they exist?), and the presupposed causal link (does it exist?).

If the existence of the causal link (PGC) is rejected, no amount of empirical evidence gathered on either side of the causal link (cause or effect) will change the conviction that AGW is invalid. Any claim that more cause or more effect points in the direction of validity of the AGW theory will be dismissed (post hoc ergo propter hoc). Because the underwriting of the causal link is derived from support of the natural sciences, and because this support in turn is vested on trust of natural scientists rather than the understanding of natural scientific theory, validity of AGW is granted only in so far as individual natural scientists are trusted. In a post-truth era, and remembering that politicians are among the least trusted people in Western nations, the engaging of natural scientists in political debates is not helping in this respect. Scientists should categorically refuse political debate and scientific activism if they want to maintain their credibility.

Ideology is not about fact, but about faith, said Joseph Goebbels (Longerich 2010). So if you believe that global warming is a myth, and $I$ believe that global warming is a myth, and mainstream media confirms that the science is uncertain, then we can safely maintain status quo and our love of Tina. Forever?

\section{Depletion}

"It is not the creation of wealth that is wrong, but the love of money for its own sake."

- Margaret Thatcher

"I saw a report yesterday. There's so much oil, all over the world, they don't know where to dump it. And Saudi Arabia says, 'Oh, there's too much oil.' Theythey came back yesterday. Did you see the report? They want to reduce oil production. Do you think they're our friends? They're not our friends." 
Tina believes that she should fill the Earth and subdue it, and have dominion over the fish of the sea and over the birds of the heavens and over every living thing that moves on the Earth. Still, natural resources (like fertile land, oceans, forests), mineral resources (like rare earths, uranium, silver) and fossil fuels are in limited supply (McKibben 2007). Most of them are not renewable. Depletion of oil resources is inevitable and is announced by the event called Peak Oil (e.g. Strahan 2007; Roberts 2004). Deforestation of ancient tropical woods is irreversible. With present fishing quota we must fear for extinction of tuna fish, and the rapid depletion of oceans of other fish for consumption.

Because Tina demands that products are of inferior quality, in real time she not only fills up the garbage and scrapheaps all over this planet, pollutes the natural environment (water, soil and air), and produces social inequalities, but she also leaves an inhabitable world depleted of all resources needed for human survival (MEA 2005). And available evidence strongly suggests that the Earth has so many unique combined features that it proves to be the only place in the entire universe where complex life forms, such as ourselves, are possible (Ward, Brownly 2000). Or should I say, were possible?

\section{The political playing field}

\section{The socialist route}

"The problem with socialism is that eventually you run out of other people's money."

- Margaret Thatcher

"We can't let people down when they can't get any medical care, when they're sick and don't have money to go to a doctor. You help them."

- Donald Trump

Most socialist parties focus on the social externalities (e.g. inequality) but accept Tina as unalterable. Socialists myopically attempt to redistribute wealth without 
noticing its source and nature. This is comfortable for Tina, in particular when socialists accept delaying retirement age, decreasing unemployment support, decreasing wages, selling public goods, etc., in the bargain. Support of socialist parties is evaporating all over Europe. In a sad but understandable confusing of antiestablishment with anti-socialism, voters turn to nationalistic anti-migrant parties that promise to listen to the voice of the people. Anticipating plebiscite response to paternalistic governance, during the late 1990s and in the 2000s, Western governments sponsored social scientific research that tried to identify the reasons why people in democracies increasingly distrusted their governments (e.g. Kampen et al. 2006). Some political parties responded to the deficit of public trust by advocating increased public participation. Even when scholars better suited than me have identified the main deficiencies of (national) referenda (Weimer, Vining 1989; but see also Kampen, Snijkers 2003), the Netherlands, UK and Italy conducted referenda in 2016 with highly inconvenient outcomes. But with all public goods in the hands of Tina, one begs to wonder what the votes were about in any case. Good governance means decreasing the scope of public influence whilst increasing the channels of participation (Kampen 2009).

\section{The nationalist route}

"In the end, more than freedom, they wanted security. They wanted a comfortable life, and they lost it all - security, comfort, and freedom. When the Athenians finally wanted not to give to society but for society to give to them, when the freedom they wished for most was freedom from responsibility, then Athens ceased to be free and was never free again."

- Margaret Thatcher

"The American People will come first once again. My plan will begin with safety at home - which means safe neighborhoods, secure borders, and protection from terrorism. There can be no prosperity without law and order. “

— Donald Trump 

KILL YOU

Support of nationalist parties is booming all over Europe. Nationalists share with socialists the love for referenda. And like socialists, nationalist parties and populists don't discuss Tina. Sometimes unwittingly, nationalists protect her with their policies by consistently tempting the people to identify the source of their problems as either immigrants or lack of national sovereignty. Most nationalists also deny climate change and categorically ignore externalities. In fact, their policies are designed by finding detractors of the consequences of Tina by claiming that societal struggles are caused by irreconcilable differences of cultures (e.g. Islam contra Christianity). "Greed is good." The natural state of man is being materialistic, and a nation can only try to protect the materialistic interests of its own people in general (and oneself in particular). From prior experience I must recommend against the act of economically (using "economy" in its original meaning of "efficiency") combining "socialism" and "nationalism" in a single term "national-socialism" to denote such policies. One need only remember that nationalists leave Tina in her virgin state.

\section{The future of the European nations}

"Europe was created by history. America was created by philosophy."

- Margaret Thatcher

"I was in Brussels a long time ago. Twenty years ago. So beautiful, so - it's like living in a hellhole right now."

—Donald Trump, FOX news, January 2016

Among others, Slavoj Žižek claims that the greatest enemies of the European Union are the nationalist anti-migrant parties. The return to protectionist nationalist nation states (Brexit, USexit, Frexit, ...) are of course not helping Europe's integration: these moves close windows for dialogue, and when diplomacy fails Clausewitz becomes relevant again. But whether the EU disintegrates or not, with the present monetary and market systems in place the only foreseeable future is war 
between regions, nations, and continents. TINA legitimizes unlimited global looting. The global system will end in violent collapse, and if Hegel is right, start right over again. Recall Albert Einstein's famous quote when he claimed that "I know not with what weapons World War III will be fought, but World War IV will be fought with sticks and stones." But perhaps he too, was optimistic.

One of the major goals of science is to establish (in)validity of "common sense." We have a civil duty to tell our students that societies, including entire scientific departments, can make consistent erratic choices. The love for Tina drives people crazy. When a society considers global warming and polluting caused by fossil fuels as mere externalities, this is an aberration, and maintaining such situations is pathology. This does not make social science politicized or value-biased in any way: it is a simple anthropological observation that people can choose policies that are self-destructive (see Diamond 2005).

People can also further other policies, of course. If people want to allocate their own labor, money must be nationalized or abandoned altogether. We can chose to use a token money (i.e. money that has no assets like gold backing its value, i.e. money like euro, dollar, yen, yuan, etc.) and have a periodic ritual each 4 years or so when both the accumulations and the deficits (debt) are deleted and the game starts over. If people want to fight climate change and depletion, they must re-allocate their resources, which means abandoning the individual profit system in favor of a collective profit system based on renewables and repairables. Exercising your power as a consumer (Reich 2007) is an important non-violent, non-cooperative way by which anyone can fight Tina. After all, concern of citizens about the ozone layer and the choice of consumers for alternatives forced industry to abandon CFKs in the 1980s (see Oreskes, Conway 2011). Decreasing meat consumption is well within your powers. Another interesting possibility is the decision to sell your goods and services only to people who can prove that their income is lower than the average national income. With these re-allocations in place, the need for migration and social action, and of course war, will gradually disappear.

But I don't see any of this happen. We are too much in love with Tina. And Tina fights back, for instance, by abandoning cash (so you have no way of holding capital outside banks who already own and spend your savings any way it pleases), by 


\section{KILL YOU}

passing legislation making it illegal to consume homegrown vegetables, by banning "fake news sites", and by a million other unforeseen ways. As for myself, having been held hostage by Tina for all my life, I've learned to love her because of Stockholm syndrome.

"I don't think there will be a woman prime minister in my lifetime."

- Margaret Thatcher

"The point is that you can't be too greedy. "

- Donald Trump

\section{Acknowledgements}

Some of my dearest friends read this essay for readability, but responsibility remains of course, mine. Except for drafting the diagrams in Figure 1-3, I don't claim any originality. Much if not all of the ideas and conclusions have been reached independently by others, for instance the late UK economist Tony Atkinson, the UK born Belgian comedian Nigel Williams (who, so I discovered after writing, made a book and dvd called "FUCK TINA!"), and many, many others. A continuing source of inspiration is Jacque Fresco's Venus Project (www.thevenusproject.com).

A quick post-truth library of the topics covered in Figure 1 is:

Monetary system: "97\% Owned - Economic Truth documentary”, 2012, Queuepolitely.

Monetary system, market system, externalities: "The Choice is Ours", 2016, The Venus Project.

Climate change: An Inconvenient Truth, 2006, Director: Guggenheim.

Depletion: “There's No Tomorrow", 2012, Director: Dermot O'Connor; Home, 2009, The Home

Project.

\section{Bibliography}

\section{Quotes}

Unless referenced otherwise, the quotes were collected from the websites www.brainyquote.com (Donald Trump) and www.goodreads.com (Margaret Thatcher).

Brenner R. (1998), The economics of global turbulence, Verso, London.

Diamond J. (2005), Collapse. How societies choose to fail or succeed, Penguin, London.

Feyerabend P. (1987), Farewell to reason, Biddles Ltd, London.

Graziana A. (2003), The monetary theory of production, Cambridge University Press, Cambridge, UK. 
Johnson A.H. (1909), The disappearance of the small landowner, Oxford University Press, Oxford.

Kampen J.K. (2011), A methodological note on the making of causal statements in the debate on anthropogenic global warming, „Theoretical and Applied Climatology” vol. 104 no.3, pp. 423-427.

Kampen J.K. (2012), Circuit theory and interest. A simple method for the allocation of debt, „Economic \& Environmental Studies”, vol. 21 no. 1, pp. 9-21.

Kampen J.K. (2009), Good governance at the local level. Toward a global village or a city republic?, „Economic and Environmental Studies”, vol. 9 no 1, pp. 11-29.

Kampen J.K. (2010), On the (in)consistency of citizen and municipal level indicators of social capital and local government performance, ,Social Indicators Research”, vol. 97 no. 2, pp. 213-228.

Kampen J.K., Van de Walle S., Bouckaert G. (2006), Assessing the relation between satisfaction with public service delivery and trust in government. The impact of the predisposition of citizens toward Government on evaluations of its performance, „Public Performance \& Management Review”, vol. 29 no. 4, pp. 387-404.

Kampen J.K., Snijkers K. (2003), e-Democracy. A critical evaluation of the ultimate e-dream, „Social Science Computer Review”, vol. 21 no. 4, pp. 491-496.

Longerich P. (2010), Goebbels. A biography, Random House, New York.

Marwijk R. van, Elands B.H.M., Kampen J.K., Terlouw S., Pitt D., Opdam P. (2012), Public perceptions of the attractiveness of restored nature, „Restoration Ecology”, vol. 20 no. 6, pp. 773-780.

McKibben B. (2007), Deep economy. Economics as if the world mattered, Oneworld Publications, Oxford.

MEA (Millennium Ecosystem Assessment) (2005), Ecosystems and human well-being. Synthesis, www.unep.org/maweb/documents/document.356.aspx.pdf [03.01.2017].

Piketty T. (2013), Le capital au XXIe siècle, Éditions du Seuil, Paris.

Oreskes N., Conway E.M. (2011), Merchants of doubt. How a handful of scientists obscured the truth on issues from tobacco smoke to global warming, Bloomsbury Press, London.

Oxfam (2005), Richest $1 \%$ will own more than all the rest by 2016,

www.oxfam.org/en/pressroom/pressreleases/2015-01-19/richest-1-will-own-more-all-rest-2016 [05.01.2017].

Quay P.D., Tilbrook B., Wong C.S. (1992), Oceanic uptake of fossil fuel $\mathrm{CO}_{2}$. Carbon-13 evidence, „Science”, vol. 256, pp. 74-79.

Reich R.B. (2010), Supercapitalism. The transformation of business, democracy, and everyday life, Random House, New York.

Roberts P. (2004), The end of oil. The decline of the petroleum economy and the rise of a new energy order, Bloomsbury, London. 
THE WORLD IN THE POST-TRUTH ERA OR HOW TOO MUCH LOVE OF TINA WILL KILL YOU

Stiglitz J. (2006), Making globalization work, Penguin, London.

Strahan D. (2007), The last oil shock. A survival guide to the imminent extinction Petroleum Man, John Murray, London.

Stuiver M., Burk R.L., Quay P.D. (1984), 13C/12C ratios and the transfer of biospheric carbon to the atmosphere, „Journal of Geophysical Research”, vol. 89 no. 11, pp. 731-748.

Swanborn P. (1996), A common base for quality control criteria in quantitative and qualitative research, „Quality and Quantity”, vol. 30 no. 1, pp. 19-35.

Tobi H., Kampen J.K. (2017), Research design. The methodology for interdisciplinary research framework, „Quality and Quantity (Open Access)”, DOI: 10.1007/s11135-017-0513-8.

Toulmin S. (1990), Cosmopolis. The hidden agenda of modernity, University of Chicago Press, Chicago.

Ward P.D., Brownlee D. (2004), Rare Earth. Why complex life is uncommon in the universe, Copernicus Books, New York.

Weimer D.L., Vining A.R. (1989), Policy analysis. Concepts and practice, Prentice-Hall, London. 


\section{Świat w erze postprawdy lub w jaki sposób zabije cię zbyt dużo milości TINA}

\section{Streszczenie}

Cel: Zarówno politycy, jak i naukowcy zmagają się z pokusą, aby udzielać prostych odpowiedzi na skomplikowane pytania. W artykule tym podjęto próbę zwięzłego zarysowania dzisiejszych problemów na poziomie globalnym, a jako punkt startowy przyjęto pytanie: „Jak szybko upadnie Unia Europejska?".

Układ / metody badawcze: Natura tematyki wskazuje raczej na holistyczne podejście interpretacyjne aniżeli na systematyczne podejście redukcjonistyczne. Przedstawiono krótkie dyskusje dotyczące oddzielnych, aczkolwiek powiązanych wzajemnie i nachodzących na siebie naturalnych i społecznych domen badawczych, ilustrujące potrzebę wykwalifikowanych multidyscyplinarnych mówców, zdolnych rozróżniać fakty od ,alternatywnych faktów”.

Wnioski / wyniki: Zwykłe antropologiczne obserwacje, zgodnie z którymi ludzie są w stanie wybrać politykę polegającą na samodestrukcji, niekoniecznie czynią nauki społeczne upolitycznionymi bądź nastawionymi na wartość. Społeczeństwo uznające globalne ocieplenie, wyczerpywanie się i zanieczyszczenia spowodowane przez paliwa kopalne za zaledwie efekty zewnętrzne, dokonuje demonstracyjnego nieobliczalnego wyboru. Ponieważ jednym $\mathrm{z}$ podstawowych celów nauki jest ustalenie (nie)zasadności „wspólnego sensu”, akademicy mają obowiązek mówienia studentom, że społeczeństwa, włączając całe środowiska naukowe, mogą dokonywać ciągłych nieodpowiedzialnych wyborów.

Oryginalność / wartość artykułu: Artykuł może wspomóc naukowców i praktyków w rozpoczęciu spoglądania na ich obszary badawcze w (o wiele) głębszym globalnym kontekście.

Słowa kluczowe: system monetarny, system rynkowy, nierówność, zmiana klimatu, wyczerpienie zasobów naturalnych

JEL: P10, P28, P36, Q20, Q40, Q50. 